Nevşehir Bilim ve Teknoloji Dergisi Cilt 5(2) 142-157 2016

DOI: 10.17100/nevbiltek.284738

URL: http://dx.doi.org/10.17100/nevbiltek.284738

\title{
Kırşehir İlinin Örtüaltı Tarım Potansiyelinin Belirlenmesi
}

\author{
Sedat Boyacı ${ }^{1, *}$, Adil Akyüz ${ }^{2}$, A. Nafi Baytorun ${ }^{3}$, Ali Çaylı ${ }^{4}$ \\ ${ }^{1}$ Ahi Üniversitesi, Ziraat Fakültesi, Biyosistem Mühendisliği Bölümü, Kırşehir \\ ${ }^{2}$ Kahramanmaraş Sütçü Imam Üniversitesi, Ziraat Fakültesi, Biyosistem Mühendisliği Bölümü,
}

Kahramanmaraş

${ }^{3}$ Çukurova Üniversitesi, Ziraat Fakültesi, Tarımsal Yapılar ve Sulama Bölümü, Adana

${ }^{4}$ Kahramanmaraş Sütçü Imam Üniversitesi, Türkoğlu MYO, Kahramanmaraş

Öz

\begin{abstract}
Akdeniz bölgesi başta olmak üzere Ege, Marmara ve Karadeniz kıyı bölgeleri ile bazı mikroklima alanlarda yoğunlaşan örtüaltı tarımı, son yıllarda İç Anadolu ve Doğu Anadolu bölgelerinde bulunan jeotermal enerji kaynaklarının kullanılmaya başlanmasıyla birlikte gelişim göstermeye devam etmektedir. Gıda, Tarım ve Hayvancılık Bakanlı̆̆ının kırsal kalkınma yatırımlarının desteklenmesi programı kapsamında, alternatif enerji kullanan (biyogaz, jeotermal vs.) seralarda \% 50 hibe desteği sağlanması, jeotermal sulara sahip olan bölgelerimizde jeotermal seracılığı gündeme getirmiştir. İç Anadolu Bölgesinin karasal iklim özelliğine sahip Kırşehir ilinde mevcut jeotermal kaynakların varlığına ilaveten bakanlık tarafindan yapılan desteklemeler il'de örtüaltı tarım faaliyetlerine bir ivme kazandırmıştır. Bu çalışmada, sahip olduğu jeotermal kaynaklar ile ülkemiz örtüaltı tarımında alternatif bölge olma özelliği gösteren Kırşehir ilinin uzun yıllar iklimsel verileri, coğrafi konumu ve tarımsal yapısı dikkate alınarak örtüaltı tarım potansiyeli araştırılmıştır. Örtüaltı tarımı açısından Kırşehir ilinin 1960-2015 yılları arası uzun yıllık iklim verileri incelendiğinde, sıcaklıkların arttığı, bağıl nem oranının da azalma eğiliminde olduğu belirlenmiştir. Bunun yanında, ilde meydana gelen uzun yıllar (56 yıl) sıcaklık ve bağıl nem değerlerinden yararlanılarak yapılan zaman serisi tahmininde tahmin fonksiyonu Quadratik bir model olarak elde edilmiştir. Buna ilişkin sicaklık fonksiyonu $\mathrm{Yt}=11.780-0.0652 \mathrm{t}+0.001414 * \mathrm{t}^{2}$, bağıl nem için $\mathrm{Yt}=63.41+0,151 \mathrm{t}-$ $0.00387 \mathrm{t}^{2}$ olarak bulunmuştur.
\end{abstract}

Anahtar Kelimeler: Örtüaltı, tarım potansiyeli, Kırşehir

\section{Determination of Greenhouse Agriculture Potential of The Kırşehir Province}

\begin{abstract}
Greenhouse cultivation concentrated on, primarily in the Mediterranean region, and Aegean, Marmara and Black Sea coastal areas and some microclimate areas, continue to be developed in conjunction with the introduction of the geothermal energy resources in recent years, existed in Central Anatolia and Eastern Anatolia regions. With 50\% grant support in the greenhouses, which use alternative energy (biogas, geothermal, etc.), in the scope of rural development investments support programme of Ministry of food agriculture and livestock, geothermal greenhouses have been brought up in the regions with geothermal water. In addition to the presence of geothermal resources in Kırşehir province, which has a continental climate in Central Anatolia region, also through the supports made by the Ministry, greenhouse agriculture activities have been accelerated. In this study we have investigated greenhouse agricultural potential of Kırşehir province, taking into account the climatic data based on long years, geographic location and agricultural structure of Kırşehir province with the alternative region property in respect of greenhouse agriculture due to its geothermal resources. Greenhouse agriculture in the province in terms of long years of climate data from 1960-2015 year are an increase in temperature is analyzed, the relative humidity was determined to be in decline. Besides, the province occurred in the long years (56 years) temperature and relative humidity values created by using the time series prediction in the prediction function is obtained as a quadratic model. The relevant temperature function $\mathrm{Yt}=11.780-0.0652 \mathrm{t}+0.001414 * \mathrm{t}^{2}$, for relative humidity $\mathrm{Yt}=$ $63.41+0.151 \mathrm{t}-0.00387 \mathrm{t}^{2}$ was found.
\end{abstract}

Keywords: Greenhouse, agricultural potential, Kırşehir

* e-mail: sedat.boyaci@ahievran.edu.tr 


\section{Giriş}

Birim alandan yüksek verim alınmasını sağlayarak küçük alanların marjinal olarak değerlendirilmesine olanak veren örtüaltı tarımı, aynı zamanda yıl içerisinde düzenli bir işgücü kullanımı sağlaması nedeniyle de ülkemizdeki en önemli tarımsal faaliyetlerden birisi haline gelmiştir [1]. Örtüaltı tarımında kullanılan yapılar, alçak tüneller, yüksek tüneller, plastik ve cam seralar olmak üzere dört grupta incelenmektedir. Bitki yetiştirilebilmesi için çevre koşullarının olumsuz etkilerini kısmen ortadan kaldıran alçak ve yüksek tüneller sera olarak nitelendirilmemektedir. Alçak tüneller daha çok turfanda sebzecilikte kullanılan ve bitkileri çevre koşullarından kısmen koruyan yapılardır. Seralar ise isıtma ve soğutma yapılabilen dolayısıyla bitkilerin çevre koşullarından bağımsız olarak mevsim dışı yetiştirilebilmelerine olanak veren yapılardır. Yüksek tüneller ise bu iki yapı arasında geçiş teşkil eden, hem turfanda hem de mevsim dışı yetiştiricilik olmak üzere her iki amaç için de kullanılabilen, gerektiğinde 1sıtılabilen yapılardır.

Örtüaltı yetiştiriciliği, turfanda amaçlı alçak ya da yüksek tünellerde de yapılsa mevsim dışı üretim amaçlı seralarda da yapılsa tarımın diğer bitkisel üretim kolları içerisinde birim alandan en fazla gelir sağlayan dalıdır. Bu nedenle günümüzde sürekli olarak alan ve üretim artışı ile birlikte teknolojik gelişim göstermektedir. Artan teknoloji ve üretici katılımıyla, bir sektör haline gelen ve büyük kazançlar getiren örtüaltı tarımının bu avantajlarından yararlanmak isteyen üreticilerin sayısı gün geçtikçe artmaktadır. $\mathrm{Bu}$ nedenle örtüaltı aktivitesi, ekolojinin olanak tanıdığı Akdeniz, Ege, Marmara ve Karadeniz bölgelerinden sonra sıcak su kaynaklarının bulunduğu İç Anadolu ve Güneydoğu Anadolu bölgesi gibi bölgelerde de yayılım göstermeye başlamıştır. Ülkemizde 1sıtma maliyetlerinin yüksek olması nedeniyle bu bölgelerde yer alan jeotermal gibi yenilenebilir ucuz ısıtma sistemlerinin örtüaltı tarımında kullanılmasıyla birlikte ısıtma sadece dondan korunma amacıyla değil bitkilerin uygun sıcaklık değerlerinde tutulması da sağlanmış olacaktır. Bu da üretimde artışların yaşanmasını sağlayacaktır.

Bir bölgede seracıllğın yapılabilmesi için o bölgenin iklim değerleri bitki gelişimi için gerekli olan sınır değerlerle karş̧laştırılmalıdır. Seralarda bitki gelişimi için gerekli iklim kriterleri şu şekilde özetlenebilir [2 ve 3]:

1) Seralardaki en düşük sıcaklık $0^{\circ} \mathrm{C}$ 'nin üzerinde olmalıdır. Aylık minimum ortalama sıcaklık 7 ${ }^{\circ} \mathrm{C}$ 'nin üzerinde olduğu durumlarda, ortaya çıkan düşük sıcaklık riskleri ihmal edilebilir.

2) Seralarda yetiştirilen domates biber, hıyar vb sebzelerin $17-27^{\circ} \mathrm{C}$ 'ye adapte oldukları dikkate alınarak serada günlük ortalama sıcaklığın $12-22^{\circ} \mathrm{C}$ olması gerekir. Günlük ortalama sıcaklığın $12^{\circ} \mathrm{C}^{\prime}$ nin altına düştüğü koşullarda seralar gece 1 sıtıllmalı, $22^{\circ} \mathrm{C}^{\prime}$ nin üzerine çıktı̆̆ında da soğutma yapılmalı veya seralar boş bırakılmalıdır.

3) Serada maksimum sıcaklık kesinlikle $35-40^{\circ} \mathrm{C}$ 'nin üstüne çıkmamalıdır.

4) Kasım, Aralık ve Ocak aylarındaki minimum güneşlenme süresi 500-550 h olmalıdır.

5) Günlük radyasyon toplamı $2300 \mathrm{Wh} / \mathrm{m}^{2}$ gün olmalıdır. Seralarda optimum bitki gelişimi için sınır değer $1000 \mathrm{Wh} / \mathrm{m}^{2}$ gün olarak kabul edilmektedir.

6) Toprak sıcaklığı en az $15^{\circ} \mathrm{C}$ olmalıdır.

7) Serada bağıl nem değerleri \% 60-70 arasında olmalıdır.

Karasal iklim kuşağında yer alan Kırşehir ili sahip olduğu iklim ve jeotermal kaynaklar ile ülkemizde örtüaltı tarımda alternatif bir bölge olma özelliği göstermektedir. Ancak, bugüne kadar bu 
potansiyel değerlendirilememiştir. Bu nedenle bu çalışmada coğrafi konum ve ulaşım, iklimsel özellikler ile tarımsal yapı ve bugünkü durum faktörleri göz önüne alınarak Kırşehir’in örtüaltı tarımı potansiyeli incelenmiştir.

\section{Materyal ve Metot}

Çalışmada, Kırşehir ili Meteoroloji Bölge Müdürlüğü istasyonlarından sağlanan uzun yıllara ait 56 yıllık (1960-2015) iklim verileri kullanılmıştır [4]. Elde edilen 56 yıllık sıcaklık ve bağıl nem değerlerinde yararlanarak zaman serisi analizleri yapılmış ve 5 yıllık sıcaklık ve bağıl nem tahmininde bulunulmuştur. Analizler MINITAB-16 paket programında yapılmıştır. Çalışmada trend analizleri araştırmacıların kullandığı yönteme göre belirlenmiştir [5 ve 6]. Buna göre, Trendlerin belirlenmesinde, sıcaklık ve bağıl nem değerleri için lineer, exponential ve kuvadratik denklemler denenmiş, $\mathrm{R}^{2}$ (determinasyon katsayıs1), MAPE (Mutlak Ortalama Yüzde Hata), MAD (Mutlak Ortalama Hata) ve MSD (Ortalama Standart Hata) gibi istatistiki sonuçlar elde edilmiştir. En uygun denklem tipinin belirlenmesi için, bu sonuçlar arasından determinasyon katsayısı ve söz konusu hata büyüklükleri dikkate alınarak denklem tipleri karşılaştırılmış, en iyi temsil gücüne sahip (denklem tipleri arasında yüksek $\mathrm{R}^{2}$ düşük hata) denklem seçilmiştir [7]. Analizler sonucunda en uygun denklem tipi kuvadratik olarak elde edilmiştir. Denklemin matematiksel formu $\mathrm{Y}=\mathrm{a}+\mathrm{bX}+\mathrm{cX} \mathrm{X}^{2}$ şeklindedir. Burada $\mathrm{Y}=$ ilgili yıla ait tahmin değeri, $\mathrm{a}=$ sabit katsayı, b ve c= sıcaklık ve bağıl nem değerlerine ilişkin hesaplanan katsayılar, $\mathrm{X}=$ zaman’ dır. Kırşehir ilinde niteliklerine göre örtü altı tarım alanları ve üretim miktarları Türkiye İstatistik Kurumu verilerine [8], Tarımsal yapı ve üretime ait veriler ise Kırşehir İl Gıda Tarım ve Hayvancılık Müdürlüğü kaynaklarından elde edilmiştir [9]. Elde edilen bulgular Çizelge ve Şekiller yardımıyla ortaya konularak Kırşehir ilinin örtüaltı tarım potansiyelinin belirlenmesi amacıyla tartışılmıştır.

\section{Bulgular ve Tartışma}

\subsection{Kırşehir İlinde Niteliklerine Göre Örtü Altı Tarım Alanları ve Üretim Miktarları}

Ülkemiz niteliklerine göre örtüaltı tarım alanları varlığı 2014 yılı itibarıyla toplam 649118 dekardır. Alan bakımından ilk sırada Akdeniz Bölgesi (\% 79.67) gelirken, Akdeniz Bölgesini Ege (\% 11.53), Karadeniz (\% 4.63), Marmara (\% 2.90), Güneydoğu Anadolu (\% 0.24), İç Anadolu (\% 0.71) ve Doğu Anadolu Bölgeleri (\% 0.09) takip etmektedir. Bunun, 80976 dekarı (\% 12.47) cam sera, 298651 dekarı (\% 46.01) plastik sera, 112771 dekarı (\% 17.37) yüksek tünel, 156720 dekarı (\% 24.14) alçak tünel alanlardan oluştuğu Çizelge 1'de görülmektedir [8].

Çizelge 1. Ülkemiz ve Bölgelerin niteliklerine göre örtüaltı tarım alanları ve türleri toplamı

\begin{tabular}{cccccc}
\hline Bölge Adı & Cam sera (dekar) & Plastik sera (dekar) & Yüksek tünel (dekar) & Alçak tünel (dekar) & Toplam (dekar) \\
Türkiye & 80976 & 298651 & 112771 & 156720 & 649118 \\
Akdeniz & 73687 & 236990 & 71998 & 134476 & 717151 \\
Ege & 6714 & 48163 & 13202 & 6743 & 15251 \\
Karadeniz & 7 & 2299 & 12476 & 96 & 30035 \\
Marmara & 260 & 5805 & 12644 & 94 & 18804 \\
Güneydoğu Anadolu & 154 & 1265 & 46 & 17 & 1559 \\
İç Anadolu & 139 & 3316 & 1108 & 134 & 4579 \\
Doğu Anadolu & 4 & 467 & & 616 \\
\hline
\end{tabular}


İç Anadolu Bölgesinde yer alan Kırşehir ili ise 2014 yılı itibarıyla bölgede 4579 dekar alanın 410 dekarına sahiptir. $\mathrm{Bu}$ değer İç Anadolu Bölgesinin \% 8.96’na sahip olduğunu göstermektedir. Niteliklerine göre bakıldığında 251 dekarı (\% 61.22) plastik sera, 153 dekarı (\% 37.32) yüksek tünel, 6 dekarı (\%1.46) alçak tünellerden meydana gelmektedir. Kırşehir ilinin son 5 yıllık niteliklerine göre örtüaltı tarım alanları varlığına bakıldığında artış içerisinde olduğu söylenebilir (Çizelge 2).

Çizelge 2. Kırşehir ilinin niteliklerine göre örtüaltı tarım alanları ve türleri toplamı

\begin{tabular}{|c|c|c|c|c|c|}
\hline Tür (dekar) & 2010 & 2011 & 2012 & 2013 & 2014 \\
\hline Cam sera & - & - & - & - & - \\
\hline Plastik sera & 76 & 96 & 170 & 250 & 251 \\
\hline Yüksek tünel & 160 & 160 & 147 & 151 & 153 \\
\hline Alçak tünel & - & - & - & - & - \\
\hline Toplam & 236 & 256 & 317 & 401 & 410 \\
\hline
\end{tabular}

Ülkemiz örtüaltı üretim miktarlarına 2014 yılı itibarıyla bakıldığında toplam 6564125 ton dur. Miktar bakımından ilk sırada Akdeniz Bölgesi 5124126 ton (\%78.13) yer alırken, Akdeniz Bölgesini, Ege Bölgesi 909763 ton (\% 13.87), Karadeniz Bölgesi 248425 ton (\% 3.77), Marmara Bölgesi 235399 ton (\% 3.18), Güneydoğu Anadolu Bölgesi 19728 ton (\% 0.30), İç Anadolu Bölgesi 14645 ton (\% 0.65) ve Doğu Anadolu Bölgesi 6256 ton (\% 0.10) olarak takip etmektedir. Üretilen ürünlerde ilk sırayı 3284578 ton (\% 50.08) domates, 1092734 ton (\% 16.66) hiyar, 653343 ton (\% 9.96) karpuz, 528770 ton (\% 8.06) biber vb.ürünlerin yer aldığı Çizelge 3’te verilmiştir [8]. İç Anadolu Bölgesinde yer alan Kırşehir ili ise bölgede üretilen 42625 ton örtüaltı üretiminin 3793 tonunu üretmektedir. Bu değer, İç Anadolu Bölgesinin \% 8.90 üretimine denk gelmektedir. Üretilen ürünlerden ilk sirada 3580 ton (\% 94.38) ile domates gelirken, diğer ürünler ise marul, patlıcan, fasulye biber, hıyar ve diğer ürünlerden oluşmaktadır. Kırşehir ilinin son 5 yıllık örtüaltı üretim miktarlarına bakıldığında artış içerisinde olduğu Çizelge 4'de görülmektedir.

Coğrafi alan olarak 7 bölgeye ayrılan ülkemizde İç Anadolu Bölgesinin niteliklerine göre örtüaltı tarım alanı ve üretim miktarı bakımından Akdeniz, Ege, Karadeniz ve Marmara Bölgelerinden sonra geldiği görülmektedir. Kırşehir ili ise İç Anadolu Bölgesi illeri içerisinde ise örtüaltı alanı ve üretim miktarı bakımından ikinci sırada yer aldığı ve yıllar itibariyle bu miktarların arttığı görülmektedir. İl'de örtüaltında yetiştirilen ürünler başta domates olmak üzere ağırlıklı olarak sebze üretimi olarak gerçekleştirilmektedir. İç Anadolu Bölgesi örtüaltı tarımında ikinci sırada yer alan Kırşehir ili jeotermal kaynaklara sahip olması ve Gıda, Tarım ve Hayvancılık Bakanlığının kırsal kalkınma yatırımlarının desteklenmesi programı kapsamında, alternatif enerji kullanan (biyogaz, jeotermal vs.) seralarda $\% 50$ hibe desteği sağlanması ile ilerleyen yıllarda il'de örtüaltı aktivitesinde olumlu gelişmelerin yaşanmasını mümkün kılmaktadır. 
Boyacı S., , Akyüz A., Baytorun AN., Çaylı A.

\begin{tabular}{|c|c|c|c|c|c|c|c|c|c|c|c|c|c|}
\hline Bölge Adı & $\begin{array}{c}\text { Toplam } \\
\text { (ton) }\end{array}$ & $\begin{array}{l}\text { Biber } \\
\text { (ton) }\end{array}$ & $\begin{array}{l}\text { Çilek } \\
\text { (ton) }\end{array}$ & $\begin{array}{c}\text { Domates } \\
\text { (ton) }\end{array}$ & $\begin{array}{l}\text { Fasulye (Taze) } \\
\text { (ton) }\end{array}$ & $\begin{array}{l}\text { Hiyar } \\
\text { (ton) }\end{array}$ & $\begin{array}{l}\text { Kabak (Sakız) } \\
\text { (ton) }\end{array}$ & $\begin{array}{l}\text { Karpuz } \\
\text { (ton) }\end{array}$ & $\begin{array}{l}\text { Kavun } \\
\text { (ton) }\end{array}$ & $\begin{array}{l}\text { Marul } \\
\text { (ton) }\end{array}$ & $\begin{array}{l}\text { Muz } \\
\text { (ton) }\end{array}$ & $\begin{array}{l}\text { Patlican } \\
\text { (ton) }\end{array}$ & $\begin{array}{l}\text { Diğer } \\
\text { (ton) }\end{array}$ \\
\hline Türkiye & 6564125 & 528988 & 158564 & 3285570 & 46008 & 1095626 & 108086 & 653343 & 143889 & 85452 & 180088 & 261874 & 16637 \\
\hline Akdeniz & 5124126 & 510076 & 116264 & 2553940 & 28846 & 666729 & 99775 & 600880 & 125443 & 14878 & 180081 & 224917 & 2297 \\
\hline Ege & 909763 & 1524 & 42234 & 578600 & 13508 & 206795 & 5943 & 12563 & 751 & 14229 & - & 32561 & 1055 \\
\hline Marmara & 208472 & 1474 & 32 & 39732 & 787 & 128338 & 5 & 0 & 6 & 35480 & 0 & 57 & 2561 \\
\hline $\begin{array}{l}\text { Karadeniz } \\
\text { Güneydoğu }\end{array}$ & 247374 & 13981 & 16 & 77861 & 2740 & 66923 & 2353 & 39900 & 17680 & 18219 & 0 & 3934 & 3767 \\
\hline Anadolu & 19728 & 512 & - & 12928 & - & 6007 & - & - & 9 & - & - & 272 & - \\
\hline İç Anadolu & 42623 & 1154 & 6 & 20187 & 83 & 13176 & 4 & 0 & $\mathbf{0}$ & 1911 & 7 & 55 & 6040 \\
\hline Doğu Anadolu & 6256 & 49 & 12 & 1330 & 0 & 4766 & 0 & 0 & 0 & 22 & 0 & 40 & 37 \\
\hline
\end{tabular}

Çizelge 4. Kırşehir ilinin örtüaltı üretim miktarları

\begin{tabular}{|c|c|c|c|c|c|}
\hline Ürünler (ton) & 2010 & 2011 & 2012 & 2013 & 2014 \\
\hline Biber & 22 & 22 & 22 & 22 & 22 \\
\hline Domates & 49 & 449 & 1908 & 3557 & 3580 \\
\hline Fasulye (Taze) & 27 & 27 & 27 & 27 & 29 \\
\hline Hiyar & 24 & 24 & 4 & 6 & 8 \\
\hline Marul & 34 & 34 & 32 & 33 & 35 \\
\hline Patlican & 30 & 30 & 30 & 30 & 30 \\
\hline Diğer & 91 & 91 & 85 & 82 & 89 \\
\hline Toplam & 277 & 677 & 2108 & 3757 & 3793 \\
\hline
\end{tabular}




\subsection{Coğrafi Konum ve Ulaşım}

Dünyada $30-40^{\circ}$ enlem kuşakları arasında kalan şeridin örtü altı tarımı açısından en şanslı bölgeler olduğuna dikkat çekilmektedir. $30^{\circ}$ enlemin altında yer alan ülkelerde yüksek sera içi sıcaklıklarını düşürmek için yapılan soğutmanın, $40^{\circ}$ enlemin üzerinde yer alan ülkelerde de sera sıcaklıklarını yükseltmek için yapılan 1sıtmanın yetiştiricilik maliyetini yükselttiğinden sera tarımını güçleştirmektedir [10 ve 11]. Kırşehir ili dünya üzerindeki konumu bakımından incelendiğinde $38^{\circ} 50^{\prime}$ $39^{\circ} 50^{\prime}$ kuzey enlemleri ile $33^{\circ} 30^{\prime}-34^{\circ} 50^{\prime}$ doğu boylamları arasındadır. Buna göre Kırşehir ili için enlem ve boylam bakımından örtüaltı tarımının gelişmesini engelleyecek coğrafik bir engelin bulunmadığı görülmektedir. Kırşehir ilinin haritası ve coğrafi konumu Şekil 1'de verilmiştir [12].

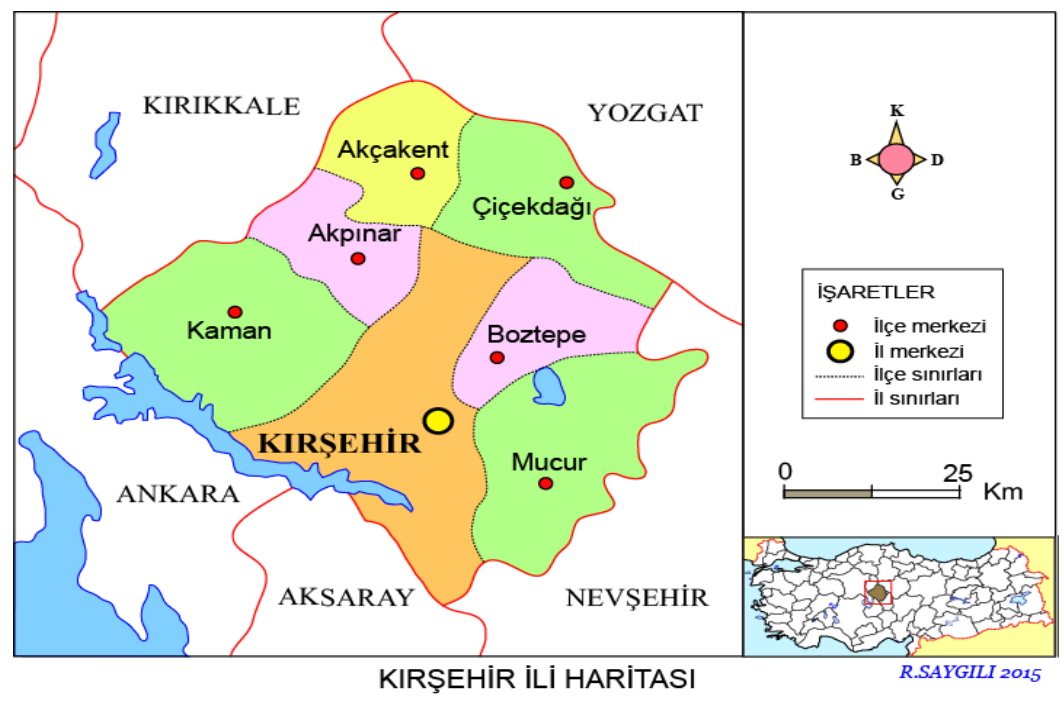

Şekil 1. Kırşehir ilinin haritası ve coğrafi konumu

Kırşehir ili doğu ve güneydoğuda Nevşehir, güneyde Niğde ve Aksaray, Batı ve güneybatıda Ankara, kuzeybatıda Kırıkkale, kuzey ve kuzeydoğuda Yozgat illeri ile çevrilmiştir. Merkez, Kaman, Çiçekdağı, Mucur, Boztepe, Akpınar ve Akçakent olmak üzere 7 ilçesi bulunmaktadır. Bu ilçelerde İç Anadolu’nun karasal iklimi hüküm sürmektedir. İç Anadolu Bölgesinin ortasında yer alan Kırşehir doğudan batıya güneyden kuzeye giden karayolu ulaşım ağının üzerinde bulunması nedeniyle Türkiye'nin kolay ulaşılabilen illeri arasındadır.

Tarımsal ürünlerin pazarlanabilmesinde yakınlık önemli rol oynamaktadır [13]. Araştırıcılar, jeotermal kaynaklara sahip Güney Marmara Bölümünün özellikle iktisadi coğrafya şartları açısından (Ulaşım, pazarlama gibi) bölge bu faaliyetin gelişme gösterebileceği ve üretimin yaygınlaşabileceği büyük bir potansiyele sahip olduğunu bildirmiştir [14]. Kırşehir ilinde komşu olduğu iller arasındaki mesafe ile seracıllı̆ın gelişmiş olduğu Akdeniz ve Ege illerine uzaklıkları çok daha fazla olduğundan bu bölgelerden örtüaltı ürünü satın alması durumunda ulaşım maliyetlerinin çok daha fazla olacağı açıktır. Bu maliyet aynı zamanda ürün fiyatlarına da yansıyacağından Kırşehir'in örtüaltı üretiminin artması neticesinde ürünlerin çevre illere pazarlanması konusunda sıkıntı çekmeyeceği görülmektedir. 
Boyacı S., , Akyüz A., Baytorun AN., Çaylı A.

\section{3. İklimsel Özellikler}

Kırşehir ilinin uzun yıllar meteorolojik verileri Çizelge 5'de verilmiştir.

Çizelge 5. Kırșehir iline ait uzun yıllık meteorolojik verilerin aylara göre ortalama değerleri

\begin{tabular}{|c|c|c|c|c|c|c|c|c|c|c|c|c|}
\hline AYLAR & 1 & 2 & 3 & 4 & 5 & 6 & 7 & 8 & 9 & 10 & 11 & 12 \\
\hline Ort. sicaklık & -0.14 & 1.25 & 5.46 & 10.66 & 15.39 & 19.67 & 23.18 & 22.91 & 18.26 & 12.43 & 6.25 & 1.96 \\
\hline Ort. mak. sicaklık & 12.12 & 14.38 & 20.57 & 25.04 & 28.65 & 32.44 & 35.43 & 35.23 & 31.93 & 27.32 & 19.90 & 14.40 \\
\hline Mak. sicaklık & 17.60 & 19.50 & 27.30 & 30.90 & 32.20 & 35.60 & 40.20 & 39.40 & 36.20 & 32.80 & 24.30 & 19.50 \\
\hline Ort. min. sicaklik & -13.23 & -12.44 & -7.62 & -2.01 & 3.01 & 7.24 & 10.99 & 10.77 & 5.40 & -0.22 & -5.78 & -9.91 \\
\hline Min. sicaklık & -22.60 & -24.60 & -21.80 & -8.20 & -1.40 & 2.60 & 6.40 & 5.90 & 1.80 & -6.60 & -14.80 & -22.00 \\
\hline Bağıl nem & 78.28 & 74.33 & 67.59 & 63.66 & 60.70 & 54.21 & 48.02 & 48.35 & 52.87 & 63.52 & 72.52 & 78.70 \\
\hline Güneşlenme Süresi & 3.12 & 4.13 & 5.24 & 6.4 & 8.51 & 10.53 & 12.01 & 11.24 & 9.36 & 7.07 & 5.09 & 3.12 \\
\hline $\begin{array}{l}\text { Güneşlenme Şiddeti } \\
\left(\mathrm{kWh} / \mathrm{m}^{2} \text {.gün) }\right.\end{array}$ & 2.06 & 2.96 & 4.07 & 4.90 & 5.85 & 6.46 & 6.58 & 5.94 & 4.96 & 3.52 & 2.40 & 1.82 \\
\hline Donlu günler sayısı & 23.10 & 19.00 & 13.7 & 2.6 & - & - & - & - & - & 1.3 & 11.0 & 19.4 \\
\hline Açık gün sayısı & 3.6 & 2.8 & 4.4 & 3.3 & 5.0 & 9.4 & 16.3 & 17.0 & 14.5 & 9.6 & 5.7 & 3.4 \\
\hline Ort. rüzgar hızı & 2.0 & 2.3 & 2.5 & 2.5 & 2.4 & 2.9 & 3.6 & 3.5 & 2.7 & 2.2 & 1.9 & 1.9 \\
\hline Hakim rüzgar yönü & $\mathrm{N}$ & $\mathrm{N}$ & $\mathrm{N}$ & $\mathrm{N}$ & $\mathrm{N}$ & $\mathrm{N}$ & $\mathrm{N}$ & $\mathrm{N}$ & $\mathrm{N}$ & $\mathrm{N}$ & $\mathrm{N}$ & $\mathrm{N}$ \\
\hline
\end{tabular}

Buna göre, Kasım-Nisan ayları arasında günlük ortalama sıcaklıklar $12^{\circ} \mathrm{C}$ 'nin altında, minimum sıcaklık ortalamaları ise $0^{\circ} \mathrm{C}$ 'nin altındadır. Bu dönemde kaliteli ve yüksek bir verim elde edebilmek için 1sıtma yapılması gerekmektedir. Ancak Nisan aylında ortalama sıcaklık $7^{\circ} \mathrm{C}$ 'den daha yüksek olduğundan bu aydaki kısa süreli düşük sıcaklıklar ihmal edilebilir. Mayıs, Haziran ve Ekim aylarında ortalama sıcaklıkların $12-22^{\circ} \mathrm{C}$ arasında olması bu dönemlerde doğal havalandırmanın yeterli olabileceğini göstermektedir. Temmuz - Ağustos ayları arasında ki dönemde ortalama sıcaklıklar $22^{\circ} \mathrm{C}^{\prime}$ nin üstünde olduğundan optimum koşulların sağlanması için bu aylarda da soğutma yapılması gerekmektedir. Temmuz-Ağustos aylarında ortalama sıcaklıkların optimumun biraz üzerinde olması ve $30^{\circ} \mathrm{C}$ yi geçmemesi nedeniyle bu aylardaki soğutma gereksinimi ihmal edilebilir. Temmuz ve Ağustos aylarında ortalama maksimum sıcaklılar $35^{\circ} \mathrm{C}$ dolayında olmasına karşın bu aylarda da rüzgar hızının yüksek olması doğal havalandırmaya yardımcı olabilecek bir faktördür. Havalandırma açıklıklarının iyi planlanması ile iç sıcaklık değerleri, dış sıcaklık değerine kadar düşürülebilir. Seralarda \% 60-90 aralığındaki bağıl nemin bitkiler üzerinde çok az etkisi vardır. Bağıl nemin \% 60’ın altına düşmesi su stresine neden olur iken \% 95'in üzerindeki bağıl nem değerleri fungal hastalıkların çıkmasına neden olmaktadır [3 ve 15]. İlde ortalama bağıl nem değeri en fazla aralık ayında \% 78.70’dir. Bu nedenle ilin bağıl nem değerlerinin yetiştiricilik açısından sorun yaratmayacak düzeyde olduğu görülmektedir. Kırşehir iline ait uzun yıllar (1960-2015) ortalama aylık sıcaklık değerleri ile 2006-2015 yıllarını kapsayan 10 yıllık periyotta ait ortalama aylık sıcaklık ve bağıl nem değerleri Çizelge 6 ve Çizelge 7’de verilmiştir. 
Nevşehir Bilim ve Teknoloji Dergisi Cilt 5(2) 142-157 2016

Çizelge 6. Son on yıllık (2006-2015) sıcaklık değerleri ile uzun yılların (1960-2015) sıcaklık değerleri arasındaki farklar

\begin{tabular}{|c|c|c|c|c|c|c|c|c|c|c|c|c|c|}
\hline Periyot & Ocak & Şubat & Mart & Nisan & Mayıs & Haziran & Temmuz & Ağustos & Eylül & Ekim & Kasım & Aralık & Ylll1k \\
\hline $\begin{array}{l}1960- \\
2015\end{array}$ & -0.14 & 1.25 & 5.46 & 10.66 & 15.39 & 19.67 & 23.18 & 22.91 & 18.26 & 12.43 & 6.25 & 1.96 & 11.44 \\
\hline $\begin{array}{l}2006- \\
2015\end{array}$ & 0.04 & 1.88 & 6.28 & 10.95 & 16.00 & 20.63 & 24.15 & 24.58 & 19.46 & 13.03 & 6.45 & 1.93 & 12.12 \\
\hline Fark & 0.18 & 0.63 & 0.82 & 0.29 & 0.61 & 0.96 & 0.97 & 1.67 & 1.20 & 0.60 & 0.20 & -0.03 & 0.68 \\
\hline
\end{tabular}

Çizelge 7. Son on yıllık (2006-2015) bağıl nem değerleri ile uzun yılların (1960-2015) bağıl nem değerleri arasındaki farklar

\begin{tabular}{lccccccccccccc}
\hline Periyot & Ocak & Şubat & Mart & Nisan & Mayıs & Haziran & Temmuz & Ağustos & Eylül & Ekim & Kasım & Aralık & Yıllık \\
$1960-$ & 78.28 & 74.33 & 67.59 & 63.66 & 60.70 & 54.21 & 48.02 & 48.35 & 52.87 & 63.52 & 72.52 & 78.70 & 63.56 \\
2015 & & & & & & & & & & & & \\
$2006-$ & 80.55 & 74.57 & 66.63 & 60.11 & 56.25 & 49.85 & 41.50 & 39.81 & 45.88 & 62.20 & 71.34 & 78.52 & 60.60 \\
2015 & & & & & & & & & & & & & \\
Fark & 2.27 & 0.24 & -0.96 & -3.55 & -4.45 & -4.36 & -6.52 & -8.54 & -6.99 & -1.32 & -1.18 & -0.18 & -2.96 \\
\hline
\end{tabular}

Çizelge 6'da uzun yıllar ortalamalarına göre son 10 yılın ortalama sıcaklık değerlerinin Aralık ayında daha yüksek olduğu, özellikle yaz aylarında bu farkın $1.67^{\circ} \mathrm{C}$ ye kadar çıktığı görülmektedir. Son 10 y1lın yıllık periyotta ortalama sıcaklık değeri uzun yıllara göre $0.68^{\circ} \mathrm{C}$ daha yüksektir. 1960-2015 yılları arasında yıllık sıcaklık ortalamalarına bakıldığında, yıllık sıcaklık ortalamalarındaki değişimin artış eğiliminde olduğu söylenebilir. Bu durum, iklim değişikliği açısından olumsuz görülse de örtüaltı tarımının geleceği açısından olumlu bir iklimsel gelişmedir. Çizelge 7’ye bakıldı̆̆ında, bağıl nem değerlerinde son 10 yıllık periyotta Ocak ve Şubat ayı dışında bir düşme eğilimi görülmektedir. Sicaklıkların yükseldiği Ağustos ayında ise bağıl nem değerinde \% 17.66’lık bir azalma söz konusudur. 1960-2015 y1lları arasında y1llık bağıl nem ortalamalarına bakılacak olursa, y1llık bağıl nem ortalamalarındaki değişim azalma eğilimindedir. Sıcaklıkların arttığı dönemlerde azalan bağıl nem değeri seraların soğutma ihtiyacı olduğu dönemlerde evaporatif serinletme yöntemlerinin kullanımı için büyük bir avantaj sağlamaktadır. Uzun yıllar (1960-2015) ve son on yıllık sıcaklık ve bağıl nem değişimleri Şekil 2'de, bu değerlerin değişimi ise Şekil 3'de verilmiştir.

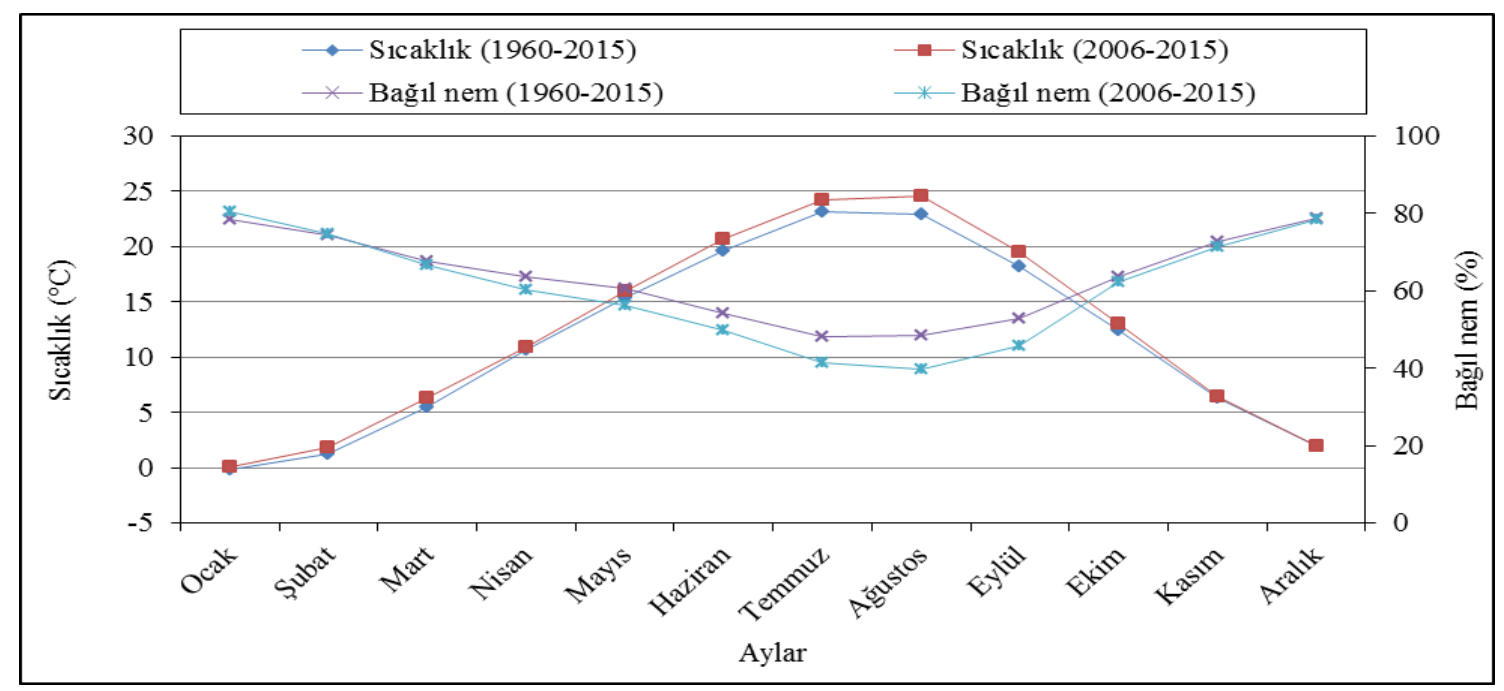

Şekil 2. Kırşehir ili (1960-2015 ve 2006-2015) yılları arasındaki aylık ortalama sıcaklık ve bağıl nem değişimleri 


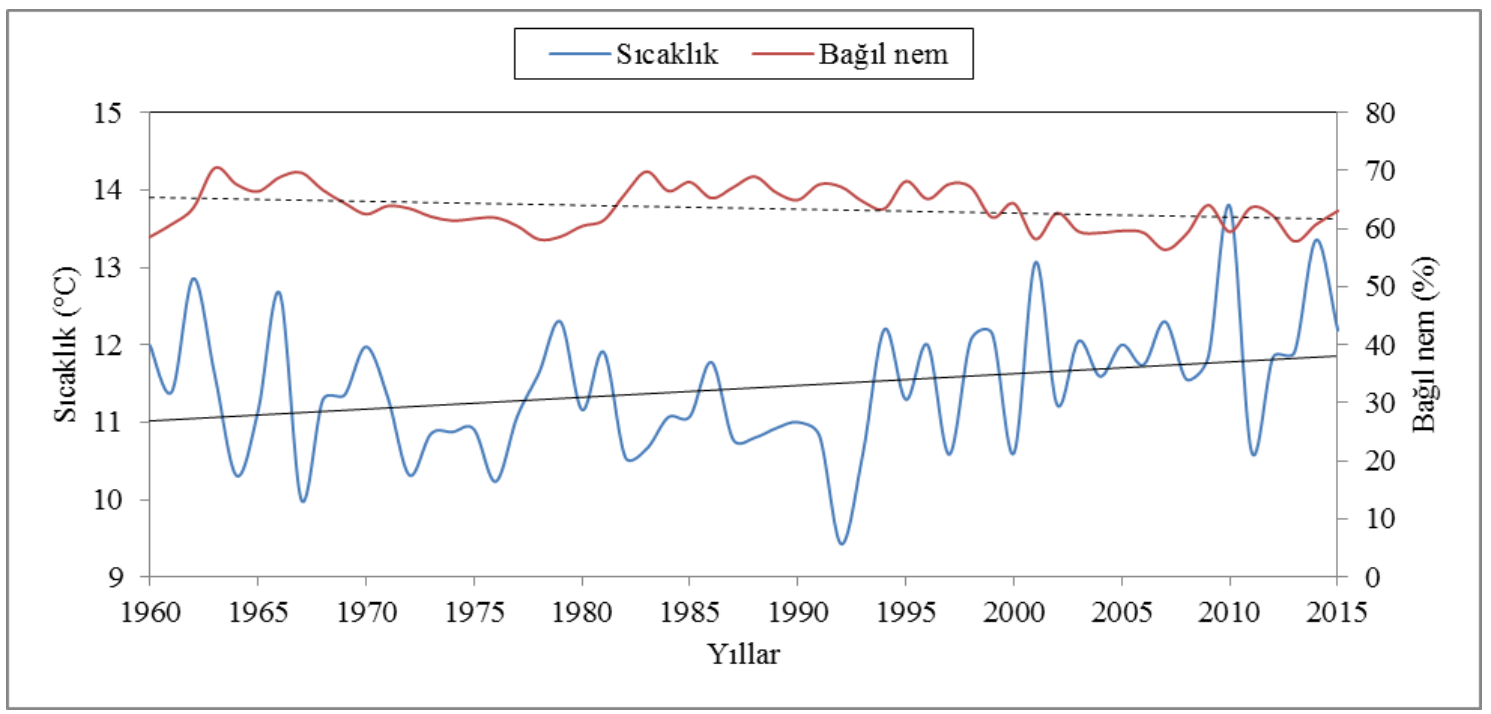

Şekil 3. Kırşehir ili (1960-2015 ve 2006-2015) yılları arasındaki yıllık ortalama sıcaklık ve bağıl nem değişimleri

1960-2015 yılları arası yıllık ortalama sıcaklık ve bağıl nem değerlerine ilişkin yapılan zaman serisi tahmininde tahmin fonksiyonu kuadratik bir model olarak elde edilmiştir. Buna ilişkin sıcaklık fonksiyonu $\mathrm{Yt}=11.780-0.0652 \mathrm{t}+0.001414 \mathrm{t}^{2}$, bağıl nem fonksiyonu ise $\mathrm{Yt}=63.41+0.151 \mathrm{t}-$ $0.00387 \mathrm{t}^{2}$ dir. kuadratik modelin kullanılma nedeni, yapılan denemeler sonucunda Lineer ve Exponantial modele göre mutlak ortalama yüzde hata, mutlak ortalama hata ve mutlak standart hatanın daha az olmasıdır. Yapılan tahmin araştırmasına göre 2016, 2017, 2018, 2019 ve 2020 yıllarına ilişkin sıcaklık ve bağıl nem tahminleri Çizelge 8'de verilmiştir.

Çizelge 8. 2016-2020 yıllarına ilişkin sıcaklık ve bağıl nem tahmin değerleri

\begin{tabular}{ccc} 
& Çizelge 8. & \\
\hline Yillar & Sicaklık Tahmin Değerleri $\left({ }^{\circ} \mathrm{C}\right)$ & Nem Tahmin Değerleri (\%) \\
2016 & 12.6564 & 59.4531 \\
2017 & 12.7538 & 59.1593 \\
2018 & 12.8540 & 58.8577 \\
2019 & 12.9570 & 58.5483 \\
2020 & 13.0629 & 58.2313 \\
\hline
\end{tabular}

Yapılan tahmin araştırmasına göre 1960-2015 yılları arasındaki yıllık ortalama sıcaklık değişimi ve 5 yıllık tahmin değerleri Şekil 4'te, bağıl nem değerleri ise Şekil 5’te verilmiştir.

Hava sıcaklığı ve solar radyasyon kontrol edilebilir sera ortamının en önemli değişkenlerden biridir. Bu değişkenler yalnızca bitki gelişimi ve verim için değil aynı zamanda enerji ihtiyacı içinde önemlidir. Seralarda enerji ihtiyacı toplam üretimin \% 40'ından fazladır [15]. Bu nedenle sera üretiminde enerji maliyetlerinin belirlenebilmesi için sera kurulacak yerin uzun yıllık verilerinden iklimlendirme yapılacak ayların belirlenmesi önemlidir. Kırşehir ili uzun yıllık ortalama sıcaklık ve ışınım değerleri Şekil 6'da verilmiştir. 


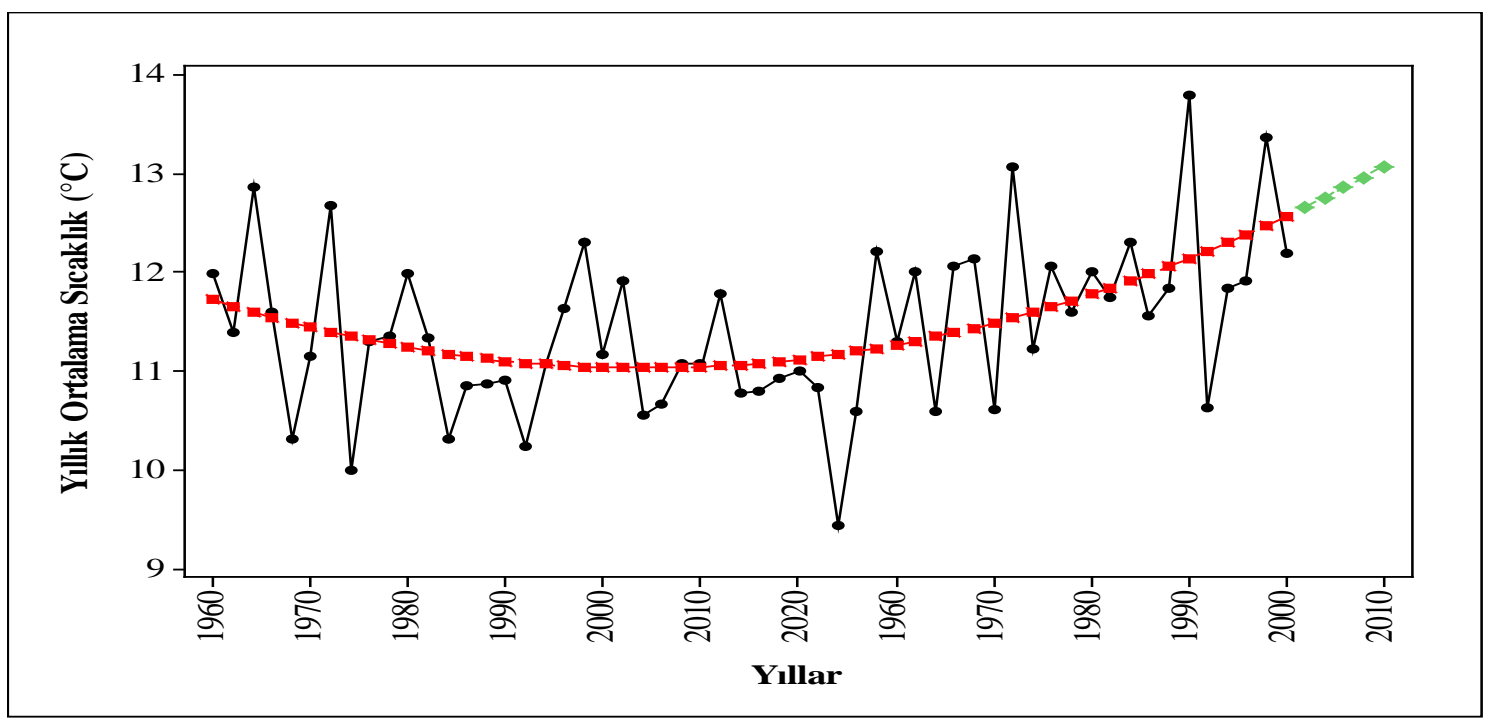

Şekil 4. 1960-2015 yılları arasındaki yıllık ortalama sıcaklık değişimi ve 5 yıllık tahmin değerleri

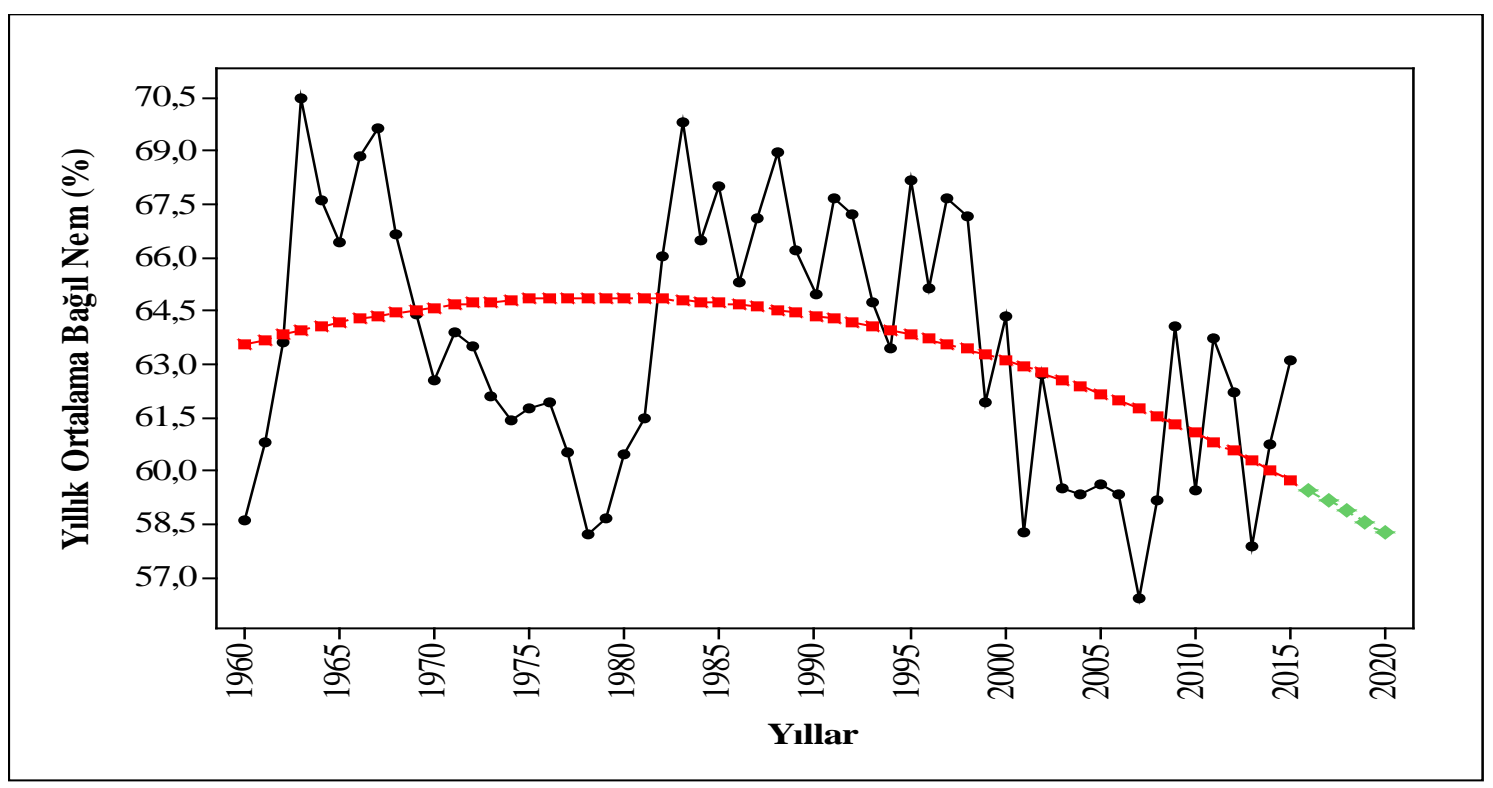

Şekil 5. 1960-2015 yılları arasındaki yıllık ortalama bağıl nem değişimi ve 5 yıllık tahmin değerleri

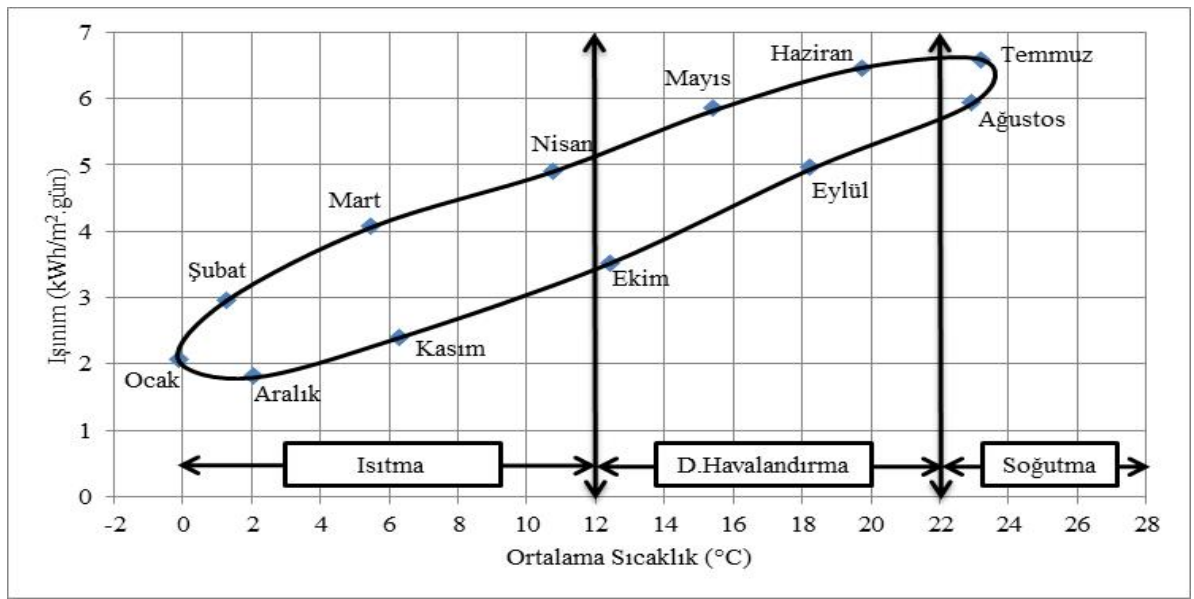

Şekil 6. Kırşehir ili uzun yıllık ortalama sıcaklık ve ışınım değerleri 
Seralarda günlük ortalama sıcaklığın $12{ }^{\circ} \mathrm{C}$ 'nin altına düştüğü koşullarda seralar gece 1sıtılmalı, 12-22 ${ }^{\circ} \mathrm{C}$ doğal havalandırma, $22{ }^{\circ} \mathrm{C}$ 'nin üzerine çıktığında da soğutma yapılmalı veya seralar boş bırakılmalıdır ve serada maksimum sıcaklık kesinlikle 35-40 ${ }^{\circ} \mathrm{C}$ 'nin üstüne çıkmamalıdır. Buna göre Kırşehir ilinde Şekil 6’ya göre Ekim ayı ilk haftalarında Nisan ayı ortalarına kadar 1sıtma, Nisan ayı ortalarından Haziran ayı ortalarına kadar ve Ağustos ayı ortalarından ekim ayı başına kadar doğal havalandırma ve Haziran ayı ortalarından Ağustos ayının ilk haftalarında serinletme ihtiyacı göstermektedir. Yürütülen bir çalışmada, günlük minimum 6 saatlik güneşlenme süresi $2.3 \mathrm{kWh} / \mathrm{m}^{2}$ gün kadar güneş enerjisine karşılık gelmektedir [16 ve 17]. Etkili yetiştiricilik için (fotosentetik aktif radyasyon-PAR) toplam güneş radyasyonu sınır değeri $1 \mathrm{kWh} / \mathrm{m}^{2}$ gün olması gerekmektedir. Kırşehir ilinin günlük toplam radyasyonu Aralık ve Ocak aylarında eşik değer $2.3 \mathrm{kWh} / \mathrm{m}^{2}$ gün'ün altında sınır değer olan $1 \mathrm{kWh} / \mathrm{m}^{2}$ gün değerinin üzerinde kalmıştır (Şekil 6).

Örtüaltı tarımında bitki gelişimini etkileyen bir diğer iklim etmeni de güneşlenme süresidir. Y1llık güneşlenme süresi coğrafi bölgelere göre değişmektedir. Türkiye’de yıllık güneşlenme süresi yönünden bölgelere göre en fazla sırasıyla Güneydoğu Anadolu Bölgesi, Akdeniz, Ege, Doğu Anadolu, İç Anadolu, Marmara ve Karadeniz Bölgeleri gelmektedir [18]. Seralarda bitki yetiştiriciliği yönünden Kasım, Aralık ve Ocak aylarında minimum güneşlenme süresinin günlük 6 saatin ve toplamda ise 500550 saatin altında olmaması istenir [2, 3, 17]. Uzun yıllar ortalamalara göre Kırşehir ilinde Kasım, Aralık ve Ocak aylarındaki toplam güneşlenme süreleri, eşik değer olan 500-550 saatin altında bulunmuştur. Kırşehir ilindeki seralarda ışıklanma süresi ve toplam günlük radyasyon miktarı kış aylarında yeterli değildir. Kırşehir'de kurulması düşünülen seraların güneşten daha fazla yararlanabilmesi için sera uzun eksen yönünün Doğu-Batı yönünde konumlandırılması gerekmektedir. Bölge seralarında Kasım, Aralık ve Ocak aylarında bitkisel üretimin optimum koşullarda sağlanması için bu aylarda 1sıtma ile birlikte yapay aydınlatmaya gereksinim duyulmaktadır.

Çizelge 1'de, Temmuz ve Ağustos aylarında ortaya çıkan ve $3 \mathrm{~m} / \mathrm{sn}$ ve daha yüksek hızlarda esen rüzgar seraların soğutulmasına yardımcı olurken, özellikle PE örtülü seralar için örtü materyalinin yıpranması bakımından bir dezavantaj olabilir. Bu durum Kırşehir’de seraların kuruluşunda rüzgar hızının dikkate alınması ve projelenerek yapılması gerekliliğini ortaya koymaktadır. Bunun yanında yetiştiricilerin plastik sera yerine cam veya polikarbon seralara yönelmesi gerekliliğini ortaya koymaktadir.

Donlu gün sayısı, ildeki örtüaltı ve turfanda yetiştiriciliği için bu kriterin üzerinde durulmasında yarar vardır. Çünkü ilk turfanda mevsimi olabilecek Ocak ve Mart ayları arasındaki üç aylık dönemde 14 ile 24 gün arasında, son turfanda olabilecek Kasım ve Aralık aylarında ilin 11 ile 20 gün arasında riskli bir dönemi vardır. Bu günlerin sayısı turfandacılık, hatta teknolojik seracılık için büyük bir dezavantajdır. Bu aylarda sera içindeki bitkilerin donma tehlikesiyle karşı karşıya olduğunu ve böylece 1sıtma yapılması gerekliliğini ortaya koymaktadır. Araştırıcılar, çift ürün üretiminin uygulandığı seralarda ilk ürünün meyve hasadı döneminin ısıtmanın yapıldığı 20 Aralık- 20 Şubat arasındaki iki aylık devreye rast getirilmesinin ısıtmayı sorun olmaktan çıkaracağı belirtilmektedir [11]. Ancak Kırşehir ilinde donlu gün sayısının fazla olması çift ürün yetiştiriciliğini engellemektedir. İlde 1sıtma yapmadan ancak 5-6 aylık dönemde ürün yetiştiriciliği yapılabileceği belirlenmiştir. İlde bu dönemlerde yetiştiricilik yapacak 
üreticilerin don tehlikesine karşı önlem olarak seralarda çatı yağmurlamasının yanında ısı perdesi ve su şiltesi gibi diğer ısı koruma yöntemlerini kullanmasında büyük yarar vardır.

\subsection{Kırşehir İlinin Jeotermal Enerji Varlığı ve Sera Isıtıımasında Kullanılabilirliği}

Ülkemizin Akdeniz bölgesinde başlayan örtüaltı tarımı ekolojik koşullara bağımlı bir gelişme göstererek Ege ve Marmara bölgelerine yayılması ve yaygınlaşmasının en önemli nedeni iklim özelliklerinin örtüaltı tarımına uygun olmasıdır. Örtü altı tarımı için en önemli iklim özelliklerinden biri olan sıcaklık ortalamalarının düşük olduğu diğer bölgelerde ise yüksek 1sıtma maliyetleri nedeniyle seracılık gelişmemiştir. Çünkü seracılık işletmelerinde 1sıtma giderleri, yetiştirme mevsimi ve konuma bağlı olarak toplam üretim giderlerinin \% 40-80’i arasında değişim gösterebilmektedir. Bu nedenle üretici 1sıtma maliyetlerini düşürmek amacıyla seralarda yetiştirme dönemi süresince bitkinin istediği optimum sıcaklık değerlerini sağlamak yerine bitkiyi dondan korumak amacıyla 1sıtmayı tercih etmekte ve çift ürün yetiştiriciliği uygulaması ile sıcaklığın en düşük olduğu Ocak-şubat aylarında yetiştiricilik yapmamayı tercih etmektedir. Düzenli ısıtma yapılmaması ve ilk ve son turfanda dönemlerinde sera içi sıcaklık değerlerinin düşük olması nedeniyle verim düşmekte bu durumda çiftçi ekonomisini etkilemektedir. Ancak son yıllarda fosil yakitlara göre daha ucuz maliyeti olan jeotermal kaynakların seracılıkta isitma amacıyla kullanılması nedeniyle, sıcaklık ortalamalarının düşük olduğu bölgelerde 1sıtma maliyetlerini azaltarak seracılığı cazip hale getirmiştir. Jeotermal kaynaklardan sıcaklığı $40^{\circ} \mathrm{C}$ 'ye kadar olanlar turizm amaçlı kullanılırken $40-180^{\circ} \mathrm{C}$ arasında olanlar ısınma amaçlı $180^{\circ} \mathrm{C}$ 'den fazla olanlar ise enerji üretimi için kullanılır [19].

Jeotermal kaynaklar bakımından ülkemizin zengin bölgelerinden olan iç Anadolu bölgesi de sıcaklık ortalamalarının düşük olduğu ve seracılığın yaygın olmadığı bölgelerimizdendir. İç Anadolu bölgesi içerisinde yer alan Kırşehir ilinde 7 önemli jeotermal sahası bulunmaktadır. Bu sahalar, Terme, Karakurt, Çiçekdağı Mahmutlu, Çiçekdağı Bulamaçlı, Kaman Savcılı, Mucur ve Akpınar jeotermal sahalarıdır. Bu sahalardan terme sahasında açılan 15 adet kuyunun sıcaklığ 30.3 ile $57^{\circ} \mathrm{C}$ debisi $5.2-100$ 1/sn, Karakurt sahasında açılan 4 adet kuyunun sıcaklığ $48.6-52{ }^{\circ} \mathrm{C}$, debisi 12-86 1/sn, Çiçekdağ mahmutlu sahsında açılan 2 adet kuyunun sıcaklı̆̆ $73.2-76.5^{\circ} \mathrm{C}$ debisi 40-80 1/sn, Çiçekdağı bulamaçlı sahasında açılan 2 adet kuyunun sıcaklığı 32-39 ${ }^{\circ} \mathrm{C}$, debisi 1.5-7.8 1/sn, Savcılı sahasında açılan 1 adet kuyunun sıcaklığ $34.5^{\circ} \mathrm{C}$, debisi 5 1/sn, Mucur sahasında açılan 2 adet kuyunun sıcaklığı 32.3-37 ${ }^{\circ} \mathrm{C}$, debisi 7-15 1/sn, Akpınar sahasında açılan 2 adet kuyunun sıcaklığ $132.7-32.4{ }^{\circ} \mathrm{C}$, debisi 3.5-5 1/sn arasındadır [20]. Bu kaynaklardan çıkan sıcak sular termal tesislerde, üniversite fizik tedavi ve rehabilitasyon merkezinde, konut 1sitılmasında, kurutma tesisinde ve sera 1sıtması gibi bir çok alanda kullanılmasına rağmen bu kaynakların etkin bir şekilde kullanılmadığı görülmektedir. Sera 1sıtmasında yalnızca Çiçekdağı Mahmutlu bölgesinde özel bir şirkete ait serada jeotermal kaynak ile 1sıtma yapılmaktadır.

Kütahya, Simav'da yapılan bir çalışmada, Eynal'daki seralarda Akdeniz kıyılarından farklı olarak hem daha fazla hem de daha uzun süre 1sıtma yapıldığını, yöredeki zengin jeotermal kaynaklar 1sıtma maliyetini düşürerek seracılığı cazip hale getireceğini, jeotermal dışında bir ssıtma yönteminin kullanılması durumunda maliyetler artacağından seracılığın ekonomik olmayacağını ancak kurulacak organize sera bölgesi ile modern seracillğa geçilmesi durumunda başta sulama, 1sıtma ve gübreleme 
olmak üzere seralardaki her türlü çalışma bilgisayar kontrolünde yapılabileceğini bu durumda bitkiye ihtiyacı kadar su, gübre ve 1sı verileceğinden hem önemli bir tasarruf sağlanarak kar marjının artacağını belirtmiştir [13]. Marmara Bölgesi'nde örtüaltı yetiştiriciliğinin araştırıldığı bir çalışmada, Güney Marmara Bölümü'ndeki jeotermal kaynaklar ve bölgede yüksek bir potansiyele sahip atık enerji istifade edilebilecek kaynakların başında yer aldığını belirtmiştir [14]. Seracılığın ülkemizde Akdeniz sahil şeridi yanı sıra Ege, Marmara, Karadeniz ve GAP alanı gibi geniş bir coğrafya'ya yayıldığını, ancak ihracata yönelik turfanda sebze ve süs bitki üretimi söz konusu olunca 1sitma giderlerinin az olduğu bölgeler avantajlı duruma geldiğini belirtmiştir [21]. Aydın ilindeki jeotermal enerji kaynaklarının sera ısıtmak amacıyla kullanımı üzerine yapılan bir çalışmada, alışılagelen enerji kaynaklarından elde edilen enerji bedellerinin yüksek olması nedeniyle yeni ve yenilenebilir enerji kaynaklarından sera 1sıtılmasında yararlanılmasının büyük önem kazandığını bildirmiştir. Yeni ve yenilenebilir enerji kaynaklarından olan jeotermal enerjinin sera isıtmasında kullanılması ile sera tarımının toplam üretim giderleri içerisinde büyük pay tutan 1sıtma giderinin azalacağını belirtmiştir. Ayrıca günümüz enerji varlığını korumak ve çevre kirlenmesini önlemek amacıyla fosil enerji kaynaklarının yerine doğal enerji kaynaklarından yararlanılmasının öncelikli bir gereksinim olduğunu ve son yıllarda seralarda jeotermal enerjiyle 1sıtma sistemlerinin tasarımına ilişkin araştırma ve geliştirme çalışmalarının önem kazandığını bildirmiştir [22].

Araştırmacıların diğer illerde yapmış oldukları çalışmalara bakıldığında, jeotermal enerjinin ülkemizde etkin olarak kullanılmadığı görülmektedir. Diğer illerde olduğu gibi Kırşehir İli’nde de etkin kullanılmayan jeotermal enerji gibi yenilenebilir alternatif enerjilerin seraların ssitılmasında kullanılması durumunda karlı bir örtü altı yetiştiriciliği yapmak mümkün görünmektedir. Jeotermal enerji kaynaklarına sahip diğer illerde olduğu gibi Kırşehir’de jeotermal organize sera bölgelerinin kurulması ile fosil yakıtların maliyetlerinin yüksek olması yanında çevreye dost olmaması nedeniyle ortaya çıkacak maddi ve çevresel etkiler azaltılmış olacaktır. Aynı zamanda bu bölgelerde 1sıtma maliyetleri düşürülerek ısıtmanın yetiştiricilik dönemi süresince kontrollü yapılmasının önündeki engel kaldırılmış olacaktır. Bu durum üründe verim artı̧ı ile birlikte çiftçi gelirinin yükselmesine, bölge çiftçisinin refah seviyelerinin artmasına ve bölgede yeni istihdam alanlarının açılmasına neden olacaktır.

\subsection{Tarımsal Yapının Bugünkü Durumu}

Kırşehir ili 161978 kişi şehir ve 59231 kişi kırsalda olmak üzere toplam 221209 kişilik nüfusuyla 81 il arasında altmışsekizinci sırada yer almaktadır. 2007 yılında şehirde 147073 kişi yaşarken, 5 yılda şehir nüfusu \% 10 artarak 2012 yılında 161978 kişiye ulaşmıştır. Aynı zaman aralığında il kırsalında yaşayanların sayısı ise \% 22 azalarak, 76097 kişiden 59231 kişiye düşmüştür. Kırşehir nüfusunun yaklaşı \% 27’i kırsalda (köy) yaşamakta olup, tarımla uğraşmaktadır. Kırşehir'in ilçe merkezlerinde yaşayanların büyük çoğunluğu da tarımsal faaliyetlerde bulunmaktadır. Kırşehir'de tarım sektöründe çalışanların oranı (15 yaş üstü) \% 38,6'dır.

Kırşehir, toplam 4547200 da tarım arazisine sahip olup, bunun 421760 da alanı fiilen sulu tarım arazisi vasfındadır. Kırşehir'in toprak ve topoğrafik durumu dikkate alındığında, 4547200 da olan tarım arazisinin 3662220 da sulanabilir vasıfta olduğu tespit edilmiştir. Kırşehir'in tarım arazisinin \% 80.5’i sulanabilir özellikte olmasına rağmen, ancak \% 9.3'ü sulanabilmektedir. Kırşehir ili sulanabilir arazi bakımından oldukça fakir bir görüntü vermektedir. Kırşehir'in tarımsal üretim değeri oldukça düşük olup, 
ülke içindeki payı \% 1'in altında kalmaktadır. Kırşehir'in tarımsal üretim değerinin \% 53.2'sini bitkisel üretim, \% 46.6'nı canlı hayvan ve \% 10.2'ni de hayvansal ürün değeri oluşturmaktadır. Tarım alanları, kullanım kabiliyetlerine göre I'den VIII e kadar sınıflandırıldığında, Kırşehir'in tarım alanları en fazla IV. sınıf (kısıtlı olarak toprak işlemeli tarıma elverişli) toprak grubuna girerken, bunu sırasıyla III, II, VI. ve I. sınıf toprak grupları izlemektedir. Çayır mera alanlarının ise VII. sınıf topraklar üzerinde olduğu görülmektedir.

Samsun ili ve ilçelerinde seraların iklimsel ihtiyaçlarının belirlenmesi amacıyla yaürütülen bir çalı̧̧a, Karadeniz bölgesi seracıllğını ilkbahar aylarında geççilik ve sonbaharda erkencilik açısından önemli kazançlar sağladığını [21], Tokat yöresinde seraların iklimlendirme gereksinimlerinin belirlenmesi amacıyla yürütülen çalışmada, Tokat ili özellikle ilkbahar ve yaz yetiştiriciliği ile erkenci sonbahar yetiştiriciliği bakımından Antalya ve diğer seracılık bölgelerine alternatif olmasa bile iç piyasa ve tüketim yönünden önemli bir potansiyel oluşturabilir durumda olduğunu [23], Manisa ilinde Jeotermal ısıttmalı seracılık işletmelerinin projelendirilmesi amacıyla yürütülen başka bir çalışmada, Salihli ve Ahmetli ilçelerine yapılan incelemelerde, işletme çalışanları, idarecileri ve sahipleriyle yapılan görüşmelerde, seracıllı̆ıı gelişmesinin önündeki engelleri belirleyip, karşılaşılan sorunların çözümü ile seracılığın Manisa ili ve ilgili yörelerinin tarımsal kalkınması için önemli bir firsat olduğu bildirmiştir [24].

Araştırmacıların farklı bölgelerde yapmış olduğu çalışmalardan görüldüğü üzere örtüaltı aktivitesi yörelerin tarımsal yapısına destek verdiği ve önemli kazançlar sağladığı açıktır. Tarımsal yapının iyileştirilmesine ihtiyaç duyulan Kırşehir ilinin genel tarımsal yapısına bakıldığında toprak sınıfının kısıtlı olarak toprak işlemeli tarıma elverişli olması, sulama açısından var olan imkânların kullanılamaması gibi bir çok nedenden dolayı köyden kente göçlerin yaşandığı bir ildir. Bunun en büyük göstergelerinden biride tarımsal üretim değerinin ülke içindeki payının \% 1'in altında kalmasıdır. Oysaki jeotermal kaynakların bulunduğu yerlerde oluşturulacak teknolojik organize sera bölgeleri ile topraksız kültürde yetiştirilecek bitkiler ile toprak sorunu yetiştiricilik açısından ortadan kaldırılmış olacaktır. Bunun yanında birim alandan daha fazla ürün alınması, çiftçi ekonomisini güçlendirerek köyden kente göçünde önüne geçilmiş olacaktır. Aynı zamanda bu bölgede ihtiyaç duyulan iş gücü artacağından bu bölgeler istihdam kaynağı da oluşturacaktır. Ülkemizde seracılığın yaygın olduğu Akdeniz Bölgesinde yüksek sıcaklık ve bağıl nem ile yoğun hastalık ve zararlı popülasyonu nedeniyle yaz aylarında seralar etkin kullanılamamaktadır. Aynı zamanda yaz aylarında seralarda ortaya çıkan yüksek sıcaklıkların azaltılması için gerekli serinletme sistemleri üreticiye ek maliyette getirmektedir. Hâlbuki Kırşehir'de kış aylarında fosil yakıtlara göre daha ucuz 1sıtma kaynağı olan jeotermalin kullanılması ile 1sıtma maliyetlerinin azaltılması ve yaz aylarında da sadece gölgeleme ve doğal havalandırma yapılarak yıl boyu sera içerisinde bitki yetiştirme potansiyeli bulunmaktadır. Bu yönüyle de ilde ilerleyen y1llarda örtüaltı aktivitesi bakımından önemli gelişmelere açık görülmektedir.

\section{Sonuç ve Öneriler}

Yapılan çalışmada uzun yıllık ortalama sıcaklıkların düşük, donlu gün sayısının fazla olduğu Kırşehir ilinde 1sıtma maliyetleri düşünüldüğünde bu aylarda örtüaltı tarımı yapmak ekonomik görülmemektedir. Ancak ilin sahip olduğu jeotermal kaynaklar büyük bir kısmının örtüaltı tarımı için 1sıtma açısından uygun özelliklere sahip olması nedeniyle bu aylarda yetiştiricilik açısından 1sıtma 
maliyetlerini düşürme şansı vardır. Ancak bugüne kadar ilde jeotermal seracılık için mevcut potansiyel tam olarak değerlendirilememiştir. Kırşehir'de kurulacak organize sera bölgesi ile iç pazara olduğu kadar konum itibariyle sera ürünlerine uzak olan Ankara, Kayseri, Nevşehir, Aksaray, Kırıkkale ve Yozgat gibi tüketim merkezlerinin ortasında yer alması nedeniyle komşu olduğu illere de örtüaltı ürünlerini pazarlama şansı vardır. Bu nedenle Kırşehir'in ürettiği tarımsal ürünleri pazarlama sorunu görülmemektedir. Bu yönüyle de örtüaltı tarımı açısından önemli potansiyele sahip olan Kırşehir ili örtüaltı tarımının yoğun olarak yapıldığı sıcaklık ve nemin yüksek olduğu Akdeniz bölgesi seralarına göre hastalık ve zararlılara karşı daha avantajlı görülmektedir. Aynı zamanda yaz aylarında ortalama sıcaklıkların bu bölgedeki illere göre daha düşük olması da yaz aylarında ortaya çıkacak serinletme sistemlerinin kurulum ve işletim maliyetlerinin azaltılması bakımından diğer bir avantajdır. Kırşehir'in nüfus verilerine bakıldığında kırsal nüfusun yıllar itibariyle azaldığı görülmektedir. Organize sera bölgelerinin kurulmasıyla birlikte kırsal alanlardan göçün azalacağı ve istihdamın artacağı beklenmektedir. Ülkemizde örtüaltı tarımı yapılan alanlara bakıldığında birçok bölgede seraların plansız yapıldığı, bölgenin iklim özellikleri dikkate alınmadan projelendiği görülmektedir. Bölgede kurulacak organize sera bölgesinde Kırşehir'in coğrafik ve iklim özellikleri dikkate alınarak kurulması, devlet destekleri ile teknolojik seraların yapılması için teşvik koşullarının iyileştirilmesi ile Kırşehir'in ileriki yıllarda İç Anadolu'nun olduğu kadar ülkemizin de örtüaltı tarımı bakımından bir cazibe merkezi haline dönüşmesi beklenmektedir.

\section{Kaynaklar}

[1] Sevgican, A., Tüzel, Y., Gül, A., Eltez, R.Z., “Türkiye’de Örtüaltı Yetiştiriciliği” V. Türkiye Ziraat Mühendisleri Teknik Kongresi 17-21 Ocak, Bildiriler Kitabı (II): 679-707s, Ankara, 1990.

[2] Baytorun, N., Abak, K., Üstün, S., İkiz., Ö., "GAP Alanlarında Sera Tarımı Potansiyeli ve Sahil Bölgeleri İle Karşılaş̧ırılması” GAP 1. Sebze Tarımı Sempozyumu 7-10 Mayıs, Bildiriler Kitab1, 367-374s, Şanlıurfa, 1996.

[3] Zabeltitz, c.V., "Integrated Greenhouse Systems for Mild Climates” ISBN: 978-3-642-14581-0, 29p, 2011.

[4] MGM., "Kırşehir Meteoroloji Bölge Müdürlüğü” Meteoroloji Genel Müdürlüğü, www.mgm.gov.tr/ (28.04.2015).

[5] Özoğuz, K., "Zaman Serilerinde Trend Fonksiyon Tipinin Belirlenmesi ve Yorumu”, İktisat Fakültesi Mecmuası, 42, 1-4, 2011.

[6] Doğan, H. G., Gürler, A. Z., "Türkiye Tarım Havzaları Üretim Ve Destekleme Modeli Kapsamında Yeşilırmak Tarım Havzasında Yetiştirilen Tarım Ürünlerinin Arz Duyarlılı̆̆ı” Yüzüncü Y1l Üniversitesi Tarım Bilimleri Dergisi, 25(3), 231-243, 2015.

[7] Cillov, H., 1984. İktisadi Olaylara Uygulanan İstatistik Metotları, İstanbul Üniversitesi İktisat Fakültesi Yayınları, No: 501, İstanbul.

[8] TÜİK., "Niteliklerine Göre Örtü Altı Tarım Alanları ve Örtü Altı Sebze ve Meyve Üretimi” http://tuikapp.tuik.gov.tr/Bolgesel/menuAction.do, 2015.

[9] Anonim., "Kırşehir Tarım ve Hayvancılık Stratejik Planı 2014 - 2018” 25s, Kırşehir, 2015. 
[10] Günay, A., "Seracılığımızın Yapısal Özellikleri” I. Türkiye Seracılık Kongresi 28-30 Nisan, Bildiriler Kitab1, 37-42s, Antalya, 1981.

[11] Sevgican, A., “Örtüaltı Sebzeciliği” TAV Yayınları, 176s, Yalova, 1989.

[12] Anonim., "Coğrafya Harita” http://cografyaharita.com/turkiye_mulki_idare_haritalari3.html, 2016.

[13] Kadığlu, Y., “Simav'da Jeotermal Seracılık” Marmara Coğrafya Dergisi, 28, 64-80, 2013.

[14] Taşlıgil, N., Şahin, G., "Ziraat Coğrafyası Açısından Marmara Bölgesi’nde Örtüaltı Yetiştiriciliği” Marmara Sosyal Araştırmalar Dergisi, 6, 1-17, 2014.

[15] Kittas, C., Katsoulas, N., Bartzanas, T., Bakker, S., "Greenhouse Climate Control and Energy Use. Good Agricultural Practices for Greenhouse Vegetable Crops” FAO Plant Production and Protection Paper, 217, 63-95, 2013.

[16] Castilla, N., Baeza, E., “Greenhouse Site Selection. Good Agricultural Practices for Greenhouse Vegetable Crops” FAO Plant Production and Protection Paper 217, 21-33, 2013.

[17] Nisen, A., Grafiadellis, M., Jiménez, R., La Malfa, G., Martínez-García, P.F., Monteiro, A., Verlodt, H., Villele, O., Zabeltitz, C.H., Denis, J.C., Baudoin, W., Garnaud, J.C., "Cultures Protegees en Climat Mediterraneen” FAO, Rome.

[18] EIEE., "Jeotermal Enerjisi Potansiyel Atlası" Enerji ve Tabi Kaynaklar Bakanlığı, Yenilenebilir Enerji Genel Müdürlüğü, http://www.eie.gov.tr/\# (11.05.2015).

[19] Şimşek, Ş., “Türkiye'deki Termal Kaynakların Potansiyeli ve Genel Özellikleri” Anatolia Turizm Araştırmaları Dergisi, 2(3): 5-9, 1991.

[20] Mahmutoğlu, N., "Kırşehir İli Jeotermal Çalışmaları” SDUGEO, 2(3): 9-13, 2011.

[21] Cemek, B., "Samsun İl ve İlçelerinde Seraların İklimsel İhtiyaçlarının Belirlenmesi" Ondokuz Mayıs Üniversitesi Ziraat Fakültesi Dergisi, 20(3), 34-43, 2005.

[22] Yıldız, M., “Aydın İlindeki Jeotermal Enerji Kaynaklarının Sera Isıtmak Amacıyla Kullanımı Üzerine Bir Araştırma” Fen Bilimleri Enstitüsü, Yüksek Lisans Tezi, 101s, Adana, 2010.

[23] Cemek, B., Karaman, S., Ünlükara, A., “Tokat Yöresinde Seraların İklimlendirme Gereksinimleri” Gaziosmanpaşa Üniversitesi Ziraat Fakültesi Dergisi, 23 (1), 25, 2006.

[24] Öztürk, M., “Jeotermal Isıtmalı Seracılık İşletmelerinin Projelendirilmesi: Manisa İli Örneği”" Fen Bilimleri Enstitüsü, Yüksek Lisans Tezi, 71s, Ankara, 2014. 